\title{
Motivation to Implement Diet in Hypertension Patients
}

\author{
Lukman Nugraha $^{1}$; Iin Patimah ${ }^{2 *}$; Dede Suharta $^{3}$ \\ 1,2*), 3 STIKes Karsa Husada Garut
}

\section{ARTICLE INFO}

Article history:

Received March 29, 2019

Revised May 17, 2019

Accepted May 21, 2019

\section{Keyword:}

Adherence

Diit

Hypertension

Motivation

*) corresponding author

STIKes Karsa Husada Garu

Jl. Nusa indah no. 24

Telp. (0262)4704803

Email: iin.patimah84@gmail.com

DOI:https://doi.org/10.30604/jika.v4i1.182

\begin{abstract}
A B S T R A C T
Many diseases occur due to complications of hypertension such as stroke and IHD (Ischemic Heart Disease). There complications can be prevented as early as possible if patients are adhered in the implementation of management hypertension. Adherence can arise if a person has a strong motivation to recuperate illness. This study aims to determine the correlation between the motivation diets of hypertensive patients with adherence to hypertension in the district Lengkong Jaya Garut. The type of research used is descriptive correlation, with a cross sectional approach, the sample used was 57 respondents, tools for data collection using questionnaires of motivation can adherence questionnaire, bivariate test analysis using chi-square. The results of the study showed that the majority of patients with low hypertension and compliance with hypertension were mostly nonadherent hypertensive patients. Hypothesis test results obtained p-value 0.026 means that there is a relationship between motivation and compliance with hypertension do it in District Lengkong Jaya Garut. It is recommended for nurses to do reregistration for hypertensive patients and to conduct special programs such as socialization to respondents with hypertension and provide counseling or home visits to respondents with hypertension in order to increase the motivation of hypertensive.
\end{abstract}

This is an open access article under the CC-BY-SA license.

\section{INTRODUCTION}

Hypertension is a chronic disease that causes high mortality and morbidity. This is because hypertension can cause complications of other diseases such as stroke and Ischemic Heart Disease (IHD), which are the two highest causes of death in Indonesia, so it is not strange if hypertension is called the disease silent killer. Besides hypertension, it is also one of the health problems with an increasing prevalence every year. Based on the riskesdas data, the prevalence of hypertension rose from $25.8 \%$ (Health 
research and development agency, 2013) to $34.1 \%$ (Health research and development agency, 2018).

Seeing this phenomenon the management of hypertension is very necessary in the treatment of hypertensive patients, because with good handling the complications of the disease can be avoided. Management of hypertension can be done by routine treatment, lifestyle modification and regular control (Osamor \& Owumi, 2011).

The key to managing hypertension is the adherence of the sufferer itself, hypertension becomes uncontrolled in most people who are not adherent in the management of hypertension (Binny et al., 2011) compliance is the level of patient behavior shown by following all instructions on diet, exercise, treatment, routine controls that are part of disease therapy (de la Sierra, Burnier, Antoniou, Volpe, \& Vrijens, 2017). Compliance in the management of hypertension includes adherence to changes in lifestyle, treatment and control routinely. Some lifestyle of hypertensive patients that need to be changed are dietary patterns..

With a diet can reduce risk factors that can be modified, causes of hypertension itself. Hypertension diet means limiting certain food intake which has the potential to increase blood pressure and increase nutrient intake which can reduce blood pressure in hypertensive patients. A dietary approach to preventing hypertension has been developed since 1997, while the components of a hypertensive diet include: a low-salt diet, not consuming alcohol, losing weight for those who are obese, regular exercise, increasing intake of vegetables and fruits and reducing high-fat foods (Alsaigh , Alanazi, \& Alkahtani, 2018; Tibebu, Mengistu, \& Negesa, 2017) From several hypertensive diet studies useful for hypertensive patients in: reducing blood tryliserid levels (Chiu et al., 2016), blood pressure in hypertensive patients (hermawati, 2014 ), reducing the risk of stroke (Feng et al., 2018), kidney disorders (Rebholz et al., 2016) reduce the incidence of coronary heart disease and heart failure (Salehi-Abargouei, Maghsoudi, Shirani, \& Azadbakht, 2013), reducing incidence Hypetensive Heart Failure (Zhu et al., 2013) and help in controlling blood sugar (Shirani, Salehi-Abargouei, \& Azadbakht, 2013).

Many factors related to adherence to hypertensive diets include: distance of home to health services, level of knowledge about hypertension management, motivation for treatment, family social support (Lestari, 2011; Q. Putri Rasajati, B. BudiNingrum, 2018a; Rachmawati T \& Turniani L , 2006)

Motivation is defined as an impulse in a person so that someone has strength, direction and perseverance in an effort to achieve the desired goals and fulfill their basic needs and desires (Lai, 2011; Robbins \& Judge, 2015). Motivation based on the source is divided into two, namely intrinsic and extrinsic motivation. Intrinsic motivation is motivation that originates from within such as a high enough interest to change, considerable curiosity and a desire to improve current disease conditions. While extrinsic motivation is a motivation that comes from outside such as family support, support from closest people, and support from health workers Health workers have a considerable contribution in improving compliance. Internal and external motivation to recover from current illnesses should be able to influence the adherence of hypertensive patients in the management of hypertension, especially related to diet hypertension in research (Puspita, 2016).

\section{METHOD}

The research design used was descriptive correlation. The research design uses a cross sectional approach, where data involving independent variables and dependent variables will be measured or collected at one time simultaneously). The independent variable in this study was the motivation of hypertension sufferers in doing hypertension 
and the dependent variable in this study was adherence to implementing hypertension. The population in this study all patients was suffering from hypertension in a Lengkongjaya Village in the Karangmulya Health Center working area with inclusion criteria in 121 Lengkongjaya Villages from 16 June to 16 July 2018. The sampling technique in this study was to use purposive sampling, where sampling was carried out in hypertensive patients who were present at the time of the study in a Lengkongjaya Village in the working area of the Karangmulya Health Center. The number of samples is 57 people. The research instruments in the form of questionnaires were 2 questionnaires, namely the hypertension diet compliance questionnaire which included intrinsic and extrinsic compliance as many as 10 items and a questionnaire on hypertension diet motivation (low salt diet, high and low cholesterol and 17 calories). The questionnaire was tested for validity first with a valid value of. 40.44. Bivariate analysis is used to prove the relationship and test the hypothesis in this study using Chisquare test.

\section{RESULTS AND DISCUSSION}

Univariate analysis was performed to determine the distribution of each variable both univariate and bivariate.

Table 1.

Frequency distribution

\begin{tabular}{lcc}
\hline Variable & Frequency & Percentage $(\%)$ \\
\hline Motivation & & \\
Low & 32 & 56,1 \\
High & 25 & 43,9 \\
\hline Compliance & & \\
Obey & 23 & 40,4 \\
Do not obey & 34 & 59,6 \\
\hline
\end{tabular}

Based on table 1 above, you can know more than half of respondents have low motivation of 32 people (56.1\%) As well as the compliance of more than half of the respondents categorized in a disobedient category of 34 people $(56.1 \%)$.

Tabel 2

Correlation analysis between motivation and compliance with hypertension diet

\begin{tabular}{|c|c|c|c|c|c|c|c|c|}
\hline \multicolumn{9}{|c|}{ Compliance } \\
\hline \multirow{2}{*}{ Motivation } & \multicolumn{2}{|c|}{ Obey } & \multicolumn{2}{|c|}{ Do not obey } & \multicolumn{2}{|c|}{ Total } & \multirow{2}{*}{ p value } & \multirow{2}{*}{$\begin{array}{c}\text { Contingency } \\
\text { Coefficient }\end{array}$} \\
\hline & f & $\%$ & $\mathbf{f}$ & $\%$ & f & $\%$ & & \\
\hline \multirow{2}{*}{$\begin{array}{l}\text { High } \\
\text { Low }\end{array}$} & 6 & 24,0 & 19 & 76,0 & 25 & 100 & \multirow{3}{*}{0,026} & \multirow{3}{*}{0,283} \\
\hline & 17 & 53,1 & 15 & 46,9 & 32 & 100 & & \\
\hline Total & 23 & & 34 & & 57 & 100 & & \\
\hline
\end{tabular}

Based on table 2 above the results of the correlation analysis between motivation and compliance with hypertension diit In Lengkongjaya Village, the Karangmulya Community Health Center Working Area, Garut Regency was obtained p-value $=0.026$ $<0.05$, which means that Ho is rejected and $\mathrm{Ha}$ is accepted thus it can be concluded that there is a relationship between motivation with the compliance of hypertension divisions in Lengkongjaya Village, the working area of Karangmulya Health Center,
Garut Regency in 2018. The degree of closeness of relations is obtained $\mathrm{C}=0.283$ which is in the weak category, with the direction of a positive relationship.

Compliance is the key to managing hypertensive patients so that the patient's blood pressure can be controlled properly. To improve patient compliance there are three things that must be considered, among others: ensuring that the patient has information regarding the disease, giving motivation to the patient and third to the patient in 
managing the disease (DiMatte, HaskardZolnierek, \& Martin, 2012).

Motivation is a part that must be considered in the management of hypertension. Motivation is defined as an encouragement in a person so that a person has strength, direction and perseverance in an effort to achieve desired goals and fulfill their basic needs and desires (Yorks, 2001; Burton, 2012; Robbins \& Judge, 2015). Maslow states that people are motivated because of unmet needs (Stoyanov, 2017).

Health problems such as hypertension will clearly threaten the fulfillment of basic needs ranging from lower to the highest order based on the severity of the disease or complications. When complications are fallen there is a threat that basic needs are increasingly clear and this will further increase a person's motivation to change behavior towards behavior to maintain health. Therefore, a real health disorder should make the motivation for patients to manage hypertension properly, one of them is to run a hypertension diet. Hypertension diet is the implementation of hypertension, which can reduce modifiable risk factors that cause hypertension.

In this study it is clear that there is a relationship between motivation and compliance with hypertension in a positive direction. The higher a person's motivation, the higher the compliance, the more so. Motivation becomes a driver for someone to act (Susanti, 2015), the size of the motivation that is owned will determine the fast or slow achievement of the desired goals. According to Herzberg in (Alshmemri, Shahwan-Akl, \& Maude, 2017) motivation can be from outside the extrinsic and from the inside (intrinsic). A health worker, has great potential to increase the motivation of hypertensive patients, nurses who are an integral part of health services have interventions in increasing motivation for their patients. Motivation can be in the form of knowledge, routine followup for hypertensive patients.
Hypertension diet is one of the keys to success in hypertension treatment. Hypertensive diets include a dietary approach to preventing hypertension that has been developed since 1997 while the components of a hypertensive diet include: increasing consumption of fruits, vegetables, wheat, beans, low-fat foods and reducing salt consumption, sweet drinks, and red meat and meat processed.

Hypertension diet is believed to help patients reduce blood pressure because the components contained in the diet of hypertension have the potential to lower blood pressure from the content of each food, one of which is a low salt diet can reduce sodium concentration in extracellular fluid so that fluid concentration will decrease and circulating fluid decreases. This will result in a decrease in blood pressure (Nurdiantini, I., Prastiwi, S., \& Nurmaningsari, Fortuna, Rihiantoro, Irawan, \& Ari, 2012). In an important dietary factor is patient compliance itself, here the motivational factor is important in increasing compliance. This research can help patients

Motivation cannot be observed, what is observed is the activity or perhaps the reasons for the action. . The results of this study are reinforced by the results of research conducted by (Pomegranate Sari, 2018). It is known that self-motivation can improve adherence to the implementation of a hypertensive diet. Another study that strengthens this research is research (Noorhidayah et al., 2016) about the relationship between motivation and adherence to taking antihypertensive drugs in the village of Salamerjo which has a close relationship between motivation and adherence to taking anti-hypertensive drugs. In this study there was a positive correlation with motivation, with adherence to hypertension, the motivation had a very large contribution in improving medication adherence, namely with the desire to recover from the illness, so that the respondent would naturally obey the network. 
Health workers have a positive relationship with adherence in hypertensive patients. Nurses as one of the health workers have a significant contribution in the management of hypertension because nurses are an integral part of health care (Patimah, Megawati, \& Suryawantie, 2018). A nurse can provide motivation, support or assistance in managing disease management so that it improves patient compliance (Kähkönen et al., 2015; Patimah et al., 2018; Q. Putri Rasajati, B. Budi Ningrum, 2018b).

\section{CONCLUSIONS AND RECOMENDATION}

The motivation of most hypertensive patients in the village of Lengkong Jaya in the working area of the Karangmulya Health Center in 2018 was in the low motivation category. Compliance with hypertension divisions in the majority of respondents with hypertension in the village of Lengkong Jaya, the working area of the Karangmulya Health Center in 2018 in the non-compliant category. There is a relationship between motivation and compliance with hypertension in the village of Lengkong Jaya in the working area of the Karangmulya Health Center in 2018.

Health workers are expected to always increase the motivation of hypertensive patients through various methods so that management of hypertension management can be effective.

\section{REFERENCES}

Alsaigh, S. A. S., Alanazi, M. D., \& Alkahtani, M. A. (2018). Lifestyle Modifications for Hypertension Management. The Egyptian Journal of Hospital Medicine, 70(12), 21522156.

https://doi.org/10.12816/0045044
Alshmemri, M., Shahwan-Akl, L., \& Maude, P. (2017). Herzberg's Two-Factor Theory. Life Science Journal, 14(5), 12-16.

https://doi.org/10.7537/marslsj140517. $\underline{03}$

Badan, penelitian dan pengembangan kesehatan. (2018). Riset Kesehatan Dasar. Jakarta. Retrieved from http://www.depkes.go.id/resources/do wnload/infoterkini/materi_rakorpop_2018/Hasil Riskesdas 2018.pdf

Badan penelitian dan pengembangan kesehatan. (2013). Riset Kesehatan Dasar. Jakarta. http://www.depkes.go.id/resources/do wnload/general/Hasil\%20Riskesdas\%2 02013.pdf

Binny, K., Meera, N. K., Kishore, G., Sasidharan, S., Dennis, T., \& Sekhar, M. S. (2011). Medication adherence and associated barriers in hypertension management in India. CVD Prevention and Control, 6(1), 9-13. https://doi.org/10.1016/j.cvdpc.2010.1 1.001

Burton, K. (2012). A Study of Motivation: How to Get Your Employees Moving. SPEA Honors Thesis Spring 2012. Indiana University. https://spea.indiana.edu/doc/undergrad uate/ugrd thesis2012_mgmt_burton.pd f

Chiu, S., Bergeron, N., Williams, P. T., Bray, G. A., Sutherland, B., \& Krauss, R. M. (2016). Comparison of the DASH (Dietary Approaches to Stop Hypertension) diet and a higher-fat DASH diet on blood pressure and lipids and lipoproteins: a randomized controlled trial. The American Journal of Clinical Nutrition, 103(2), 341-347. https://doi.org/10.3945/ajcn.115.12328 $\underline{1}$

de la Sierra, A., Burnier, M., Antoniou, S., Volpe, M., \& Vrijens, B. (2017). 
Current Situation of Medication Adherence in Hypertension. Frontiers in Pharmacology, 8:100, 1-8. https://doi.org/10.3389/fphar.2017.001 $\underline{00}$

Delima Sari. (2018). Hubungan Motivasi Diri Terhadap Kepatuhan Melaksanakan Diet Pada Penderita Hipertensi. Jurnal Online Mahasiswa (JOM) Bidang Ilmu Keperawatan, 5(2), 580-588. Retrieved from

https://jom.unri.ac.id/index.php/JOMP $\underline{\text { SIK/article/view/21311 }}$

DiMatte, M. R., Haskard-Zolnierek, K. B., \& Martin, L. R. (2012). Improving patient adherence: A three-factor model to guide practice. Health Psychology Review. https://doi.org/10.1080/17437199.2010 .537592

Feng, Q., Fan, S., Wu, Y., Zhou, D., Zhao, R., Liu, M., \& Song, Y. (2018). Adherence to the dietary approaches to stop hypertension diet and risk of stroke: A meta-analysis of prospective studies. Medicine, 97(38), e12450e12450.

https://doi.org/10.1097/MD.00000000 $\underline{00012450}$

Hermawati, wiwi sartika. (2014). Berdasarkan Pola Diet Dan Kebiasaan Olah Raga. Jurnal Kesehatan Masyarakat, 8(1), 8-14. Retrieved from

http://jurnal.fkm.unand.ac.id/index.php /jkma/article/view/118

Kähkönen, O., Kankkunen, P., Saaranen, T., Miettinen, H., Kyngäs, H., \& Lamidi, M.-L. (2015). Motivation is a crucial factor for adherence to a healthy lifestyle among people with coronary heart disease after percutaneous coronary intervention. Journal of Advanced Nursing, 71(10), 2364-2373. https://doi.org/10.1111/jan.12708
Lai, E. (2011). Motivation: A Literature Review Research Report. Research Reports, (April), 41. Retrieved from http://www.datec.org.uk/CHAT/chatm eta1.html

Lestari, T. (2011). Dengan Kepatuhan Diet Pada Pasien Hipertensi Di Wilayah Puskesmas Galur 1 Kulon Progo Program Studi Ilmu Keperawatan Sekolah Tinggi Ilmu Kesehatan ' Aisyiyah Yogyakarta Hipertensi Di Wilayah Puskesmas. Retrieved from http://digilib.unisayogya.ac.id/1261/1/ naskah Publikasi tiwi.pdf

Noorhidayah, S. A., Studi, P., Keperawatan, I., Kedokteran, F., Ilmu, D. A. N., \& Yogyakarta, U. M. (2016). Hubungan kepatuhan minum obat antihipertensi terhadap tekanan darah pasien hipertensi di desa salamrejo. Retrieved from

http://repository.umy.ac.id/bitstream/h andle/123456789/7325/12.NASKAHP UBLIKASI.pdf? sequence $=12 \&$ isAllo $\underline{\text { wed }=\mathrm{y}}$

Nurdiantini, I., Prastiwi, S., \& Nurmaningsari, T., Fatonah, S., Rihiantoro, T., Irawan, H., \& Ari, S. (2012). Nursing News Volume 1, Nomor 2, 2016. Journal Nursing News, XI(1), 31-37. https://doi.org/10.1021/BC049898Y

Osamor, P. E., \& Owumi, B. E. (2011). Factors associated with treatment compliance in hypertension in southwest Nigeria. Journal of Health, Population, and Nutrition, 29(6), 619628. Retrieved from https://www.ncbi.nlm.nih.gov/pubmed/ 22283036

Patimah, I., Megawati, S. W., \& Suryawantie, T. (2018). Efektivitas Metode Pembelajaran Cooperative Learning Terhadap Kemampuan Komunikasi pada Mahasiswa. Jurnal Pendidikan Keperawatan Indonesia, 4(1), 86. 
https://doi.org/10.17509/jpki.v4i1.1234 7

Puspita, E. (2016). FAKTOR-FAKTOR YANG BERHUBUNGAN DENGAN KEPATUHAN PENDERITA HIPERTENSI DALAM MENJALANI PENGOBATAN. UNIVERSITAS NEGERI SEMARANG. Retrieved from

https://lib.unnes.ac.id/23134/1/641141 1036.pdf

Rasajati, Q., Raharjo, B., \& Ningrum, D. N. (2015). Faktor-Faktor yang Berhubungan dengan Kepatuhan Pengobatan pada Penderita Hipertensi di Wilayah Kerja Puskesmas Kedungmundu Kota Semarang. Unnes Journal of Public Health,4(3). https://doi.org/10.15294/ujph.v4i3.633 $\underline{9}$

Rachmawati T, \& Turniani L. (2006). Pengaruh dukungan dosial dan pengetahuan tentang Penyakit TB terhadap motivasi untuk Sembuh penderita tuberkulosis paru yang berobat di Puskesmas. Buletin Penelitian Sistem Kesehatan, (1), 134 141. Retrieved from http://ejournal.litbang.depkes.go.id/ind ex.php/hsr/article/view/1887

Rebholz, C. M., Crews, D. C., Grams, M. E., Steffen, L. M., Levey, A. S., Miller 3rd, E. R., ... Coresh, J. (2016). DASH (Dietary Approaches to Stop Hypertension) Diet and Risk of Subsequent Kidney Disease. American Journal of Kidney Diseases: The Official Journal of the National Kidney Foundation, 68(6), 853-861. https://doi.org/10.1053/j.ajkd.2016.05. $\underline{019}$

Robbins, S. P., \& Judge, T. A. (2015). Organizational Behavior EDITION 15. (S. Yagan, Ed.), pearson (15th ed.). Retrieved from http://bba12.weebly.com/uploads/9/4/2 /8/9428277/organizational_behavior_1

\section{$\underline{5 e-}$ \\ stephen_p_robbins_timothy_a_judg e_pdf_qwerty.pdf}

Salehi-Abargouei, A., Maghsoudi, Z., Shirani, F., \& Azadbakht, L. (2013). Effects of Dietary Approaches to Stop Hypertension (DASH)-style diet on fatal or nonfatal cardiovascular diseases-Incidence: A systematic review and meta-analysis on observational prospective studies. Nutrition, 29(4), 611-618. https://doi.org/https://doi.org/10.1016/i .nut.2012.12.018

Shirani, F., Salehi-Abargouei, A., \& Azadbakht, L. (2013). Effects of Dietary Approaches to Stop Hypertension (DASH) diet on some risk for developing type 2 diabetes: A systematic review and meta-analysis on controlled clinical trials. Nutrition, 29(7), 939-947. https://doi.org/https://doi.org/10.1016/j .nut.2012.12.021

Susanti, L. (2015). Pemberian Motivasi Belajar Kepada Peserta Didik Sebagai Bentuk Aplikasi Dari Teori-Teori Belajar. PPKn Dan Hukum, 10(2), 7183. Retrieved from https://ejournal.unri.ac.id/index.php/JP B/article/download/3650/3556

Tibebu, A., Mengistu, D., \& Negesa, L. (2017). Adherence to recommended lifestyle modifications and factors associated for hypertensive patients attending chronic follow-up units of selected public hospitals in Addis Ababa, Ethiopia. Patient Preference and Adherence, 11, 323-330. https://doi.org/10.2147/PPA.S126382

Zhu, S., Sheth, S. S., Weder, A. B., Kovács, S. J., Hummel, S. L., Brook, R. D., ... Ghosh, E. (2013). Low-Sodium DASH Diet Improves Diastolic Function and Ventricular-Arterial Coupling in Hypertensive Heart Failure With Preserved Ejection Fraction. 
J urnal Aisyah: J urnal Ilmu Kesehatan, 4(1), J uni 2019, - 90

Lukman Nugraha; Iin Patimah; Dede Suharta

Circulation: Heart Failure, 6(6), 1165-1171.

https://doi.org/10.1161/circheartfailure .113 .000481 